supériorité soit numérique, soit sociale? et paraît elle le fruit du génie de la race? Question délicate, car il faut juger d'après des probabilités soulement, mais à laquelle il est permis de répondre oui.

Quel a été le berceau de la race dolichocéphale blonde? Question d'archéologie préhistorique et de physiologie. Réponse: c'est la région oû le type ostéologique le plus voisin du type dolichocéphale blond s'est trouvé soumis aux conditions météorologiques nécessaires pour le réduire à un état voisin de l'albinisme.

Où doit etre localisé ce berceau? le type dolichocéphale blond se rattachant par le squelette aux races quaternaires et néolithiques de l'Europe occidentale son berceau ne peut être cherché qu'en Europe, les conditions nécessaires d'inactinisme et d'humidité permanente qui ont déterminé sa décoloration ne se sont trouvées réalisées que dans la région voisine de la Mer du Nord, à la fin du quaternaire, et mieux encore dans la partie de cette mer alors exondée.

On arrive ainsi aux propositions suivantes:-

Le type polichocéphale blond, $H$. europceus, Linné, abusivement appelé aryen, s'est développé dans le N. O. de l'Europe, telle quelle était à la fin des temps quaternaires, par l'action des milieux sur les races dolichocéphales indigènes, ou sur une seule de ces races. Il s'est fixé par un long séjour dans ces régions. Il en est sorti par des émigrations successives à mesure que le sol s'engloutissait sous ses pieds.

Les langues et les institutions indo-européennes se sont formées quelque part en Europe sous l'action du génie de la race blonde. Cette formation est de date relativement récente, et si les blonds ont apporté de leur primitive patrie une langue proto-aryenne, elle était à un stade d'évolution qui ne permettrait probablement pas d'en reconnaitre la nature. On sait la rapidité avec laquelle varient les langues non écrites. L'état des langues indo-européennes prouve d'autre part leur origine récente.

Les langues et les institutions indo-européennes ont été ensuite implantées dans les deux tiers de l'Europe et dans une petite partie de l'Asie, par les conquètes des peuples qui en faisaient usage. Un peuple passé probablement d'Europe en Bactriane par la mer Caspienne, ou Asiatique mais conquis par des Européens a porté les langues et les institutions indo-européennes dans l'Inde. A ce rameau seul appartient le nom d'Aryen.

Tout s'éclaircit donc dès qu'on n'embrasse plus ensemble la question d'origine des langues aryennes et celle de la race blonde, dès qu'on ne confond plus les peuples indo-européens avec les blonds, conquérants d'abord, puis absorbés et devenus classe dirigeante chez des peuples de race différente.

\section{THE SCIENTIFIC ALLIANCE OF NEW YORK.}

BY JOSEPH F. JAMES, M. SC., WASHINGTON, D.C.

THE "Scientific Alliance of New York" is composed of the following societies: New York Academy of Science, Torrey Botanical Club, New York Microscopical Society, Linnæan Society of New York, New York Mineralogical Club, New York Mathematical Society, New York Section of American Chemical Society.

Two meetings have been held, of which the proceedings have been published, and as the scheme seems to mark an era in scientific matters, especially in New York City, and as it is one that is likely to result in permanent benefits to science, a notice of it does not seem out of place.

The council of the Alliance is composed of the president and two members of each of the component societies. Its president is Charles F. Cox, and its secretary and treasurer N. L. Britton. The first meeting was held on November 15, 1892, and at it addresses were made by various prominent men. Hon. Seth Low, President of Columbia College, spoke upon the advantages to the city of New York of the Alliance, and he was followed by $\mathrm{Mr}$. C. F. Cox with an address on the advantages of the alliance to the scientific societies. Mr. Cox pointed out the necessity of coopperation by the various organizations if the best results are to follow. He referred to the fact that the real materialists of the world are the so-called practical men, who measure scientific knowledge by commercial standards and in whose eyes science "is worth only what it will bring when offered in the form of dynamos, telephones, electric lights, dye stuffs, mining machinery and other merchantable wares." The object of the Alliance he held to be to furnish a sort of common ground (may we call it a clearing house?) where knowledge of what is being done in one society is conveyed to all the rest, and in this way all are kept posted in regard to what is going on and duplication of work is thereby avoided.

The third address was by Hon. Addison Brown on the need of endowment for research and publication. He referred to the example set by Professor Tyndall, who established three scholarships with $\$ 30,000$ received by him from a series of lectures delivered in this country. He has been followed by others with equally munificent gifts. He pointed out the necessity to the practical man of work in the region of pure science, but as the workmen in this region are generally those who have neither the time nor the means for original research, the necessity for an endowment to enable them to continue their work is evident. Reference was made to the difference between the German universities, where the professors are expected to do original work, leaving the teaching for instructors, and the American so-called universities and colleges where the professors seldom have the time to devote to anything outside of mere routine work. $\mathrm{He}$ mentioned the humiliating fact that at the Zoölogical Station at Naples, where Germany and Italy each maintain eight tables, Russia, Spain, Austria, and England three each, and Switzerland, Belgium and Holland one each at a cost of $\$ 500$ per annum, the United States had none, and has been dependent heretofore upon the generosity of foreign nations for the occasional use of a table. This loss is not compensated for by the fact that there are several small laboratories along the Atlantic coast of this country. The endowment of research through fellowships in colleges was also considered, and lastly a detailed reference to scientific societies in this country and England. The comparison is not flattering to our pride. In England the property, funds and equipment of the societies is nearly ten-fold greater than in America. The publications are double. No laboratories and no professors are maintained here for original research. "The English societies," he said, "distribute yearly from $\$ 25,000$ to $\$ 35,000$ for from sixty to seventy-five different scientific purposes, while ours make no such appropriations simply because there are no funds."

Dr. H. Carrington Bolton, in his plea for a library of science in New York, gave many interesting facts relative to libraries of New York and its sister cities, arguing in favor of bringing together under one roof all the libraries of the societies in the Alliance. These libraries aggregate 13,700 volumes and would form an excellent nucleus for a scientific library. Reports received from sixty libraries of New York and its vicinity show that there are $1,916,000$ volumes in them, the scientific books varying from 5 to 100 per cent. Fifteen of the libraries have over 40.000 volumes each. To house the libraries Professor Bolton outlined a plan. $\mathrm{He}$ advised having a building $100 \times 120$ feet square, four stories high in front, with a lecture room, in the rear, large enough to seat 1,000 persons. The library room should have shelves to accommodate 300,000 volumes. There should be an office for general business, several small rooms for ordinary meetings of the separate societies, photographic and microscopic laboratories and a general reception room. The plan is extensive, but let us hope that some wealth New Yorker may make it feasible.

The second joint meeting of the Alliance was held on March $2 \%$, 1893 , in memory of Dr. J. S. Newberry. The important business transacted after the reading of a memoir by Professor H. L. Fairchild, was a report of a committee recommending the establishment of an endowment fund of $\$ 25,000$ for the purpose of encouraging original research. The fund is to be known as the John Strong Newberry Fund, and is to be administered under the direction of the Council of the Scientific Alliance. Blank forms for subscriptions of any amount will be cheerfully furnished by Dr. N. L. Britton, Columbia College, New York. The money will be used for furthering researches in geology, paleontology, botany and zoölogy, in all of which subjects Dr. Newberry was interested. About $\$ 600$ in sums varying from $\$ 5$ to $\$ 100$, had been subscribed about a month ago, 